\title{
Pengembangan Kemampuan Sumber Daya Aparatur Birokrasi Lokal Dalam Penyelenggaraan Otonomi Daerah
}

\author{
HARTAWAN \\ Email: hartawan1001@gmail.com \\ Universitas Tadulako
}

\begin{abstract}
Abstrak
Reformasi birokrasi baik di tingkat pusat maupun di daerah. Reformasi ini dapat dilakukan melalui pembinaan dan pengembangan kemampuan sumber daya aparatur di daerah sebagai sarana perubahan perilaku dan pola pikir aparatur birokrasi. Pengembangan kemampuan sumber daya aparatur dapat dilakukan melalui peningkatan pendidikan formal dan kegiatan pendidikan non formal seperti pelatihan prajabatan, magang, workshop, atau dalam pengembangan code of conduct. Kegiatan ini merupakan salah satu strategis yang dapat dilakukan oleh pemerintah daerah dalam rangka merubah perilaku dan pola pikir aparatur birokrasi. Disamping itu pengembangan sumber daya aparatur dapat dilakukan dengan mengembangkan sistem rekrutmen yang profesional, tidak saja dalam memilih dan menempatkan aparat dalam suatu jabatan tertentu, tetapi sistem rekrutmen yang profesional juga diperlukan dalam penerimaan calon pegawai negeri sipil.
\end{abstract}

Keywords: Aparatur Birokrasi, Otonomi Daerah, Pengembangan, sumber daya

\section{Pendahuluan}

Tuntutan berbagai kalangan yang ada dalam masyarakat kepada Pemerintah Pusat di Jakarta untuk mengimplementasikan kebijaksanaan otonomi yang luas telah lama menjadi tuntutan politik sejak beberapa dekade lalu. Tetapi dalam era Pemerintah Orde Baru aspirasi tersebut di nilai sebagian kalangan tidak pernah direspon secara sungguh-sungguh dan hanya setengah hati dengan alasan klasik bahwa Daerah belum mempunyai kesiapan dan kemampuan, sehingga peluang dan keberhasilan untuk mengelola kewenangan yang luas tidak akan bisa dimanfaatkan dengan baik. Dibalik dari alasan tersebut ternyata tersimpan kepentingan politik Pemerintah Pusat untuk tetap melakukan dominasi kekuasaan yang sangat kuat atas Pemerintah Daerah pada hampir semua dimensi kehidupan. Akibat dominasi kekuasaan Pemerintah Pusat tersebut mengakibatkan timbulnya ketergantungan Daerah yang sangat tinggi terhadap Pemerintah Pusat, sehingga nasib pembangunan di daerah seolah-olah ditentukan oleh Pemerintah Pusat.

Tuntutan dan desakan dari berbagai kalangan kepada Pemerintah Pusat untuk memberikan otonomi yang luas kepada daerah mencapai puncaknya bersamaan dengan momentum reformasi. Puncak dari tuntutan tersebut dicabutnya Undang-undang No. 5 Tahun 1974, dan di terbitkannya Undang-undang No. 22 Tahun 1999 Tentang pemerintahan daerah dan Undang-undang No.25 Tahun 1999 Tentang Perimbangan Keuangan Antara Pemerintah Pusat dan Pemerintah daerah.

Terbitnya Undang-undang tersebut dinilai sebagian kalangan sebagai indikator keseriusan Pemerintah Pusat untuk merespon aspirasi masyarakat dan sekaligus ingin merubah sistem pemerintahan sentralistis yang selama kurang lebih 32 tahun dijalankan oleh 
Pemeintah Orde Baru yang menimbulkan implikasi negatif terhadap penyelenggaraan pemerintahan daerah menjadi sistem desentralisasi. Disamping itu, munculnya fenomena yang mengancam disintegrasi bangsa yang mengarah pada pemisahan diri dari Negara Kesatuan Republik Indonesia, seperti yang kita saksikan di berbagai media. Sehinga mautidak mau Pemerintah Pusat harus mengakomodasi tuntutan daerah dengan memberikan otonomi yang seluas-luasnya.

Pemberian kewenangan yang luas kepada Derah melalui Undang-Undang No. 22 Tahun 1999 maupun Undang-Undang No. 32 tahun 2004 dalam mengelola urusan pemerintahan dan pembangunan di satu sisi dapat dipandang sebagai kesempatan yang baik bagi Daerah untuk lebih maju dan lebih berkembang dalam upaya meningkatkan kesejahteraan masyarakat dan kualitas pelayanan publik, karena dengan otonomi, Daerah telah diberikan kewengan dan keleluasaan kepada daerah untuk mengatur dan mengurus segala sesuatu yang dianggap penting bagi kemajuan daerahnya, kecuali dalam bidang politik luar negeri, pertahanan keamanan, moneter dan fiskal, agama, peradilan..

Tetapi di sisi lain pemberian otonomi yang luas kepada daerah dapat pula di pandang sebagai tantangan baru yang cukup berat bagi pemerintah daerah atas kemampuannya dalam mengelola otonomi luas. Alasannya karena pemberian otonomi luas tersebut diberlakukan pada saat pemerintah daerah berada dalam kemampuan yang masih terbatas sebagai akibat proses belajar dan penyempitan kreatifitas di masa lalu di bawah sistem pemerinahan sentralistik. Demikian juga kualitas pendidikan aparatur birokrasi juga dipandang belum memadai dalam mendukung efektivitas penyelenggaraan pemerintahan, sebagai contoh data kualitas pendidikan aparat yang pernah dimuat dalam Harian Pikiran Rakyat Bandung pada bulan Mei 1997,. mengungkapkan tingkat pendidikan sarjana aparat birokrasi di indonesia hanya mencapai 8,65\% dan tingkat doktoral 0,01\%. Jumlah kualifikasi pendidikan ini sebagian besar bekerja di departemen pendidikan nasional (guru dan dosen), sisanya tersebar di departemen lain. Data yang relatif sama pada tahun 2011 menunjukkan bahwa tingkat pendidikan formal PNS atau aparatur sipil negara masih relatif rendah. Dari 4.646.351 jumlah aparatur sipil negara atau PNS pada tahun 2011 kualifikasi pendidikan formal terbanyak adalah Sekolah Lanjutan Tingkat Atas (SLTA) yakni 1.555.944 (33,48\%), menyusul tingkat pendidikan Strata Satu (S1) 1.514.428 (32,56\%), pendidikan Sarjana Strata Dua (S2) 105.375 (2,26\%), dan pendidikan Strata Tiga (S3) hanya $8.095(0,17 \%)$. Data ini memberi petunjuk bahwa kualitas pendidikan aparatur birokrasi di Indonesia yang bekerja diberbagai depertemen sebahagian besar hanya tamatan SLTA (Wirman Syafri, 2012).

Oleh karena itu sangat mungkin terjadi sebagaimana di kuatirkan beberapa kalangan bahwa pemberlakukan Undang-Undang No. 22 tahun 1999 menimbulkan masalah baru di daerah karena tidak diimbangi oleh kapasitas pemerintah lokal yang memadai. Sementara disisi lain hakikat otonomi tidak saja mengandung pemindahan kewenangan, tetapi juga mengandung kemampuan untuk melaksanakan tanggung jawab yaitu tanggung jawab untuk meningkatkan kualitas pelayanan dan kesejahteraan masyarakat. Sebagian konsekwesi dari tanggung jawab ini maka dalam Undang-Undang No. 22 tahun 1999 
maupun Undang-Undang No 32 tahun 2004 ditegaskan jika daerah tidak mampu menyelenggarakan otonomi, maka otonomi daerah dapat dihapus atau dapat digabung dengan daerah lain. Untuk mencegah terjadinya kekhawatiran tersebut tidak ada pilihan lain bagi pemerintah daerah kecuali mengembangkan kemampuan sumber daya aparaturnya sebagai faktor utama yang mendukung efektivitas penyelenggaraan otonomi daerah. Dalam berotonomi diperlukan birokrat profesional, karena ia perlu merencanakan, menyelenggarakan, dan mengendalikan.

Secara teoritis tujuan pemberian otonomi luas kepada daerah tidak hanya mengandung distribusi kekuasaan atau pembagian kekuasaan kepada elit politik lokal, tetapi otonomi daerah juga bertujuan untuk meningkatkan kualitas pengambilan keputusan agar keputusan sesuai dengan kebutuhan dan kepentingan masyarakat. Disamping itu pemberian otonomi kepada daerah memperpendek jenjang khirarki pengambilan keputusan sehingga pengambilan keputusan tersebut dapat di lakukan secara cepat.Dengan demikian dari sudut pandang administrasi publik, pemberian otonomi daerah bertjuuan untuk meningkatkan kualitas pelayanan publik sehingga birokrasi lokal diberikan kewenangan dan kekuasaan yang besar untuk merumuskan dan mengimpelementasikan kebijakan yang lebih sesuai kepentingan dan kebutuhan masyarakat dalam rangka meningkat kan kesejetraan masyarakat.

Namun temuan emperis menunjukan sejak jatuhnya pemerintahan Soeharto ternyata cenderung diikuti dengan semakin rendahnya kepercayaan masyarakat terhadap birokrasi publik dalam memberikan pelayanan kepada masyarakat. Krisis kepercayaan terhadap birokrasi publik, baik pusat maupun lokal di tandai dengan mengalirnya protes dan demonstrasi yang di lakukan berbagai komponen masyarakat terhadap birokrasi publik

Indikator lain yang menunjukan masih rendahnya kualitas pelayanan birokrasi lokal kepada masyarakat adalah masih lambatnya pelayanan dan masih berbelit-belitnya prosudur pelayanan perizinan, diskriminatip dalam memberikan pelayanan,dan masih merajalelanya pungutan liar (pungli) di luar ketentuan.Fenumena ini menunjukan rendahnya kualitas pelayanan birokrasi publik kepada masyarakat. Rendahnya kualitas pelayanan birokrasi publik kepada masyarakat selama ini mudah dipahami karena birokrasi publik selama ini menjadi instrumen yang efektiv bagi penguasa orde baru untuk mempertahankan. kekuasaannya baik sipil maupun militer. Dalam rezim orde baru birokrasi cenderung menempatkan dirinya lebih sebagai alat penguasa dari pada pelayan masyarakat. Dengan kata lain birokrasi dan pejabatnya lebih menempatkan dirinya sebagai penguasa dari pada sebagai pelayan. Oleh karena itu budaya dan etika pelayanan selama ini amat sulit berkembang dalam birokrasi, karena para pejabatnya lebih memposisikan diri sebagai "Tuan dari pada menjadi pelayan" sebagai Tuan mereka justru cenderung membutuhkan pelayanan dari masyarakat. Menurut Dwiyanto (2008), saat ini kita mewarisi suatu kultur pemerintahan yang berorientasi pada kekuasaan, bukan pelayanan. Sejak merdeka, kita memang hanya membangun struktur dan kultur pemerintahan feodalistik dan bernuansa emperial sehingga birokrasi kita memiliki budaya paternalisme yang menempatkan pimpinan sebagai pihak yang paling dominan. 
Berdasarkan fenomena ini, maka perlu dilakukan reformasi birokrasi baik di tingkat pusat maupun di daerah. Reformasi ini dapat dilakukan melalui pembinaan dan pengembangan kemampuan sumber daya aparatur di daerah sebagai sarana perubahan perilaku dan pola pikir aparatur birokrasi. Pengembangan kemampuan sumber daya aparatur dapat dilakukan melalui peningkatan pendidikan formal dan kegiatan pendidikan non formal seperti pelatihan prajabatan, magang, workshop, atau dalam pengembangan code of conduct. Kegiatan ini merupakan salah satu strategis yang dapat dilakukan oleh pemerintah daerah dalam rangka merubah perilaku dan pola pikir aparatur birokrasi. Disamping itu pengembangan sumber daya aparatur dapat dilakukan dengan mengembangkan sistem rekrutmen yang profesional, tidak saja dalam memilih dan menempatkan aparat dalam suatu jabatan tertentu, tetapi sistem rekrutmen yang profesional juga diperlukan dalam penerimaan calon pegawai negeri sipil (PNS). Bahkan menurut Prof. Dr. H.A. Kartiwa, Drs,SH,MS, dalam penerimaan calon pegawai negeri sipil di Indonesia perlu dilakukan tes psikologis (wawancara). Tujuannya adalah untuk mengetahui jiwa pengabdian seseorang dalam melayani kebutuhan masyarakat. Disamping itu, tes ini juga bertujuan untuk mengetahui kemampuan seseorang dalam membangun kerja sama dengan orang lain.

Dengan pembinaan dan pengembangan kualitas sumber daya aparat birokrasi di daerah melalui kegiatan pendidikan dan penerapan sistem rekrutmen yang profesional diharapkan dapat menumbuhkan semangat entrepreunership dan semangat reinventing government serta jiwa pengabdian dalam diri setiap aparatur di daerah yang dapat memberikan kekuatan koseptual bagi peningkatan kinerja birokrasi lokal sebagai parameter dalam mengukur tingkat keberhasilan penyelenggaraan otonomi daerah.

\section{Otonomi dan Desentralisasi}

Secara teoritis Otonomi memiliki banyak pengertian yang kemudian menimbulkan berbagai interpretasi. Salah satu makna Otonomi yang sering di artikan adalah kebebasan atau kemerdekaan bersyarat. Logeman dalam (Syafrudin, 1985) memberi rumusan otonomi adalah kebebasan bergerak yang diberikan kepada daerah, berarti memberi kesempatan kepadanya untuk menggunakan prakarsanya sendiri dari segala macam kekuasaannya untuk mengurus kepentingan umum (penduduk). Pemerintahan yang demikian itu kata Logeman dinamakan Otonomi.

Selznick (1992) memandang otonomi sebagai salah satu strategi untuk menjaga integritas suatu lembaga dimana nilai-nilai dan kompetensi dari lembaga tersebut di pelihara dan dilindungi oleh elit-elitnya. Karena itu otonomi daerah secara tidak langsung juga mengandung adanya pengakuan terhadap eksistensi keleluasaan elit-elit lokal. Holdaway, Newberry, Hickson, dan Heron (dalam PKPK, 2000) menginterprestasikan otonomi sebagai The extent to Which organizationaly relevan decision making authority is isnide the organization. Para ahli tersebut mempersepsikan sebagai jumlah dari otoritas pengambilan keputusan yang dimiliki oleh suatu organisasi. Semakin banyak otoritas pengambilan keputusan maka tingkat otonominya lebih tinggi. Bila dikaitkan dengan konsep otonomi daerah, maka suatu daerah yang memiliki banyak otoritas pengambilan keputusan dinilai 
semakin otonom. Makna lain otonomi dapat ditinjau dari asal kata atau etimologi "auto" berarti diri sendiri, dan "nomos" berarti aturan perundangan. Dengan makna ini, otonomi daerah dapat diartikan sebagai kewenangan untuk mengatur diri sendiri atau kemandirian.

Sementara itu, Terry (1995) mengatakan ada dua paradigma utama otonomi, yaitu paradigma politik dan paradigma organisasi. Menurut paradigma politik, otonomi birokrasi publik tidak mungkin ada dan tidak bakal berkembang, karena adanya kepentingan politik dari rezim yang sedang berkuasa pada tingkat yang lebih tinggi yang tentu saja terus membatasi kebebasan birokrat pada level bawah untuk membuat keputusan sendiri. Bila paradigma ini diterapkan pada otonomi daerah, maka pemerintahan daerah (kabupaten dan kota) yang merupakan subordinate dari pemerintahan pusat sulit menjadi otonom. Secara teoritis sifat subordinasi dan otonomi saling bertentangan, sehingga menurut paradigma politik otonomi tidak dapat berjalan selama posisi suatu lembaga masih merupakan suborniasi dari suatu lembaga yang lebih tinggi.

Paradigma organisasi justru memandang betapa pentingnya otonomi suatu lembaga untuk menjamin kualitas birokrasi yang bernilai dan yang diinginkan. Inisiatif, inovasi dan kreatifitas sangat diperlukan untuk menjaga kualitas pengambilan keputusan dan perkembangan suatu institusi birokrasi apabila institusi tersebut memilki otonomi. Dengan kata lain, paradigma organsisasi melihat bahwa otonomi harus ada agar suatu birokrasi dapat tumbuh dan menjaga kualitasnya sehingga dapat memberikan pelayanan yang terbaik bagi pelanggan atau masyarakat yang membutuhkan dalam rangka meningkatkan kesejahteraan masyarakat.

Paradigma ke dua otonomi ini lebih berkaitan dengan manfaat pelaksanaan otonomi sebagai perwujudan desentralisasi. Manfaat pemberian otonomi dan desentralisasi yang di kemukakan oleh para ahli juga berfariasi. Fortrman (dalam Coralie, 1989) mengemukakan manfaat desentralisasi merupakan suatu cara untuk mengembangan kapasitas lokal. Jika suatu badan lokal diserahi tanggung jawab dan sumber daya, maka kemampuannya akan berkembang atau meningkat. Sebaliknya. Jika suatu badan lokal semata-semata mengikuti kebijakan nasional, para pemuka warga masyarakat di daerah akan mempunyai investasi yang kecil didalamnya.

Pendapat yang hampir senada dikemukakan oleh Maddick (dalam Supriatna, 1993) bahwa manfaat otonomi desentralisasi adalah suatu cara untuk meningkatkan kemampuan pejabat pemerintah untuk memperoleh informasi yang lebih penting tentang kondisi daerah, merencanakan rencana-rencana daerah secara lebih responsif dan bereaksi secara lebih tepat mana kala masalah-masalah secara tidak terhindarkan dalam pelaksanaannya. Hal ini sejalan dengan pendapat Mc. Gregor (dalam Pamudji, 1986) yang mengatakan manfaat desentalisasi dan otonomi bukan hanya dapat memperbaiki kualitas pengambilan keputusan, akan tetapi juga meningkatkan kualitas pengambilan keputusan atau kebijaksanaan yang lebih sesuai dengan karateristik dan kepentingan lokal.

Dalam hubungan ini, Smith dalam hipotesisnya mengatakan makin tinggi desentralisasi atau otonomi makin besar pula rasa tanggung jawab dari pejabat-pejabat pemerintah daerah. Dari pendapat pakar tersebut diatas dapat disimpulkan bahwa manfaat 
otonomi daerah adalah untuk meningkatkan kemampuan pemerintah lokal. Kemampuan pemerintah lokal dapat diartikan sebagai kemandirian dan profesionalisme untuk mengelola berbagai kewenangan dan tanggung jawab yang dilimpahkan oleh pemerintah pusat kepada daerah dalam rangka meningkatkan pelayanan dan kesejahteraan rakyat di daerah. Dalam konteks Indonesia manfaat otonomi daerah harus juga dilihat sebagai upaya birokrasi Indonesia untuk merespon keanekaragaman Indonesia agar mampu memberikan yang terbaik.

Meskipun dengan diberlakukannya Undang-undang no 32 tahun 2004 tentang pemerintahan daerah sebagai pengganti Undang-undang no 22 tahun 1999 dimana sebagian kewenangan ditarik lagi akan tetapi tanggung jawab dan kewenangan pemerintah lokal tetap masih sangat besar terutama dengan penyelenggaraan pelayanan publik. Karena secara teoritis pelaksanaan otonomi daerah dapat meningkatkan kualitas pelayanan publik karena otonomi daerah bertujuan memperpendek tingkatan atau jenjang hirarki pengambilan keputusan, sehingga pengambilan keputusan tersebut dapat dilakukan secara lebih cepat. Selain itu otonomi daerah juga bertujuan untuk memperbesar kewenangan dan keleluasaan daerah sehingga pemerintah daerah terutama kabupaten/kota dapat merumuskan dan mengimplementasikan kebijakan dan programnya yang lebih sesuai dengan kebutuhan daerah dan tuntutan masyarakat. Otonomi daerah dari tinjauan administrasi publik juga bertujuan untuk memperpendek penyelenggaraan pemerintahan dengan kostituennya sehingga penyelenggaraan pemerintahan daerah akan dapat merespon aspirasi dan kebutuhan masyarakat secara lebih cepat. Dengan demikian dengan adanya otonomi daerah dapat diciptakan adanya kesetaraan posisi tawar antara birokrasi lokal sebagai penyelanggara jasa pelayanan dengan masyarakat sebagai pengguna jasa pelayanan. Akan tetapi temuan emperis di beberapa daerah di Indonesia baik provinsi maupun kabupaten/kota menunjukkan bahwa pelaksanaan otonomi daerah belum dapat meningkatkan kualitas pelayanan publik, dan temuan ini banyak diungkapkan melalui hasil penelitian.

\section{Pengembangan Sumber Daya Aparatur Birokrasi Lokal dan Strateginya}

Menurut Frank J. Goodnow yang dikutip oleh Nicholas Henry (1988) bahwa administrasi negara atau birokrasi pemerintah memiliki dua fungsi yang berbeda (the distinct functions of goverment) yaitu fungsi politik dan fungsi administrasi. Fungsi politik berarti birokrasi pemerintah baik pusat maupun daerah mempunyai tugas dan fungsi untuk merumuskan kebijaksanaan negara/daerah atau yang biasa disebut perumusan pernyataan keinginan negara/rakyat (has to do with policies or expressions of the state will), oleh karena itu administrasi negara atau publik merupakan bagian dari proses politik. Sedangkan fungsi administrasi adalah berkaitan dengan pelaksanaan kebijaksanaan negara/daerah (has to do with the execution of these policies). Menurut para ahli administrasi negara/publik, kedua fungsi yang melekat pada birokrasi pemerintah yaitu fungsi perumusan kebijaksanaan negara (public policy formulation) dan fungsi pelaksanaan (public policy implementation) sama pentingnya. Hal ini juga sejalan dengan pendapat Riggs (1964) dalam tulisannya berjudul "bureaucralic Politics In Comparative Perspective" mengatakan bahwa birokrasi 
tidak hanya dapat melaksanakan fungsi politik. Efektivitas suatu masyarakat politik berkaitan dengan tingkat perimbangan kekuatan antara birokrasi negara di satu pihak dengan kekuatan gabungan ekstra birokrasi (partai, lembaga perwakilan, dan sistem pemilihan dilain pihak).

Dari uraian diatas memberi petunjuk bahwa birokrasi pemerintah baik di tingkat pusat maupun di daerah mempunyai peranan yang sangat penting dan menentukan bagi perubahan dan kemajuan bangsa/negara serta meningkatkan kesejahteraan rakyat. Dalam hubungan ini Nicholas Henry (1988) dalam bukunya berjudul Administrasi Negara Dan Masalah- Masalah Kenegaraan, mengatakan bahwa di abad XX ini, birokrasi pemerintah telah menjadi ajang perumusan kebijaksanaan negara atau penentu utama kemana negeri ini akan menuju. Ini berarti birokrasi pemerintah memegang peranan yang sangat penting dan menentukan bagi masa depan bangsa dan bernegara. Dengan demikian perubahan pola pikir dan perilaku aparatur, baik di pusat maupun lokal sungguh sangat diperlukan. Sebab dari perubahan perilaku dan pola pikir aparatur akan melahirkan inovasi dan kretivitas dalam mengelola berbagai sumber daya. Perubahan pola pikir ini dapat dilakukan melalui pendidikan sebagai sarana pengembangan kemampuan sumber daya aparatur.

Sejumlah pakar telah mengingatkan bahwa kunci utama keberhasilan suatu organisasi dalam mecapai tujuan dan sasarannya adalah terletak pada kemampuan sumber daya manusianya. F Luthan (1992) pakar perilaku organisasi mengatakan : "Sumber daya utama organisasi bukanlah teknologi dan modal tetapi manusia". Pendapat serupa diungkapkan oleg Edward III (1980) mengatakan sumber daya manusia merupakan faktor penting dan menentukan dalam mencapai efektivitas program. Kebijakan yang dibuat tidak akan mencapai hasil yang diharapkan tanpa tersedia sumber daya manusia yang memiliki kemampuan dan keterampilan yang tinggi. Oleh karena itu menurut Edward III sumber daya ini haruslah benar-benar diperhatikan.

Kedua pendapat tersebut dapat disimpulkan bahwa pengembangan sumber daya aparat dalam suatu organisasi memberi arti yang sangat penting dalam mendukung pelaksanaan otonomi luas dan bertanggung jawab. Melalui pengembangan sumber daya manusia akan membentuk manusia aparatur yang cerdas, kreatif, inovatif, etos kerja tinggi, di siplin, berwawasan kedepan dan ber kepribadian baik. Dengan kualitas seperti ini maka aparatur lokal akan mampu memasuki kehidupan baru di masa datang yang syarat dengan tantangan dan persaingan utamanya persaingan dalam peraturan global yang sangat ketat dan tidak dapat dihindari oleh pemerintahan lokal. Oleh karena itu pilihan untuk meningkatkan kemampuan aparat tidak dapat dihindari, apalagi fungsi administrasi negara (pemerintah) menjalankan dua fungsi yang berbeda yaitu merumuskan kebijaksanaan dan mengimplementasikan kebijaksanaan. Kualitas sebuah kebijakan tentu akan berpengaruh terhadap lingkungan kehidupan masyarakat dan lingkungan kehidupan masyarakat ditentukan oleh kualitas kebijakan yang dirumuskan oleh seorang aparatur.

Berdasarkan uraian tersebut terlihat, sumber daya aparatur dalam organisasi berfungsi sebagai kekuatan internal yang bersifat positif yang memungkinkan organisasi memiliki kekuatan untuk mencapai sasarannya. Sebaliknya ketidak mampuan sumber daya 
manusia akibat rendahnya produktifitas menyebabkab organisasi tidak dapat mencapai sasaran dan tujuannya.

Teori pengembangan sumber daya manusia pada hakekatnya melekat pada diri individu manusia yang sebenarnya bersumber dari teori Mc. Lelland (1961). Teori ini dikenal dengan simbol N-Ach (Need for Achievement). Teori tersebut berintikan bahwa dalam diri setiap indivindu manusia terdapat potensi untuk berprestasi. Dalil inilah yang membuat Mc. Lelland bertambah yakin bahwa kemajuan suatu bangsa dan negara belum ditentukan oleh daya alamnya yang berlimpah, melainkan ditentukan oleh mutu sumber manusianya. Lewat teori ini Mc. Lelland juga berkesimpulan bahwa N-Ach ini semacam virus yang bisa ditularkan. Jadi N-Ach bukanlah sesuatu yang di wariskan sejak lahir. Dari teori ini dapat disimpulkan nilai Achievement di kalangan aparat begitu penting sehingga timbul dorongan untuk berprestasi dan memiliki semangat kewirausahaan.

Para ahli mengemukakan bahwa sarana yang efektif untuk mengembangkan sumber daya aparat (SDM) adalah melalaui pendidikan, baik melalui pendidikan formal maupun pendidikan non-formal. Ini berarti pendidikan memberi pengaruh yang signifikan dalam rangka meningkatkan pengetahuan dan keterampilan aparatur. Rendahnya keterampilan akan berdampak negatif terhadap pengembangan diri seseorang aparatur sehingga sulit untuk memanfaatkan berbagai peluang. Sebaliknya tingginya pengetahuan dan keterampilan aparat akan berdampak positif bagi kemampuan dan sikap kerja aparat sehingga ia dapat memanfaatkan berbagai peluang bagi kemajuan daerah dan masyarakatnya. Menurut Monj Mery (1989) dalam mottonya mengatakan tugas utama seorang administrator pembangunan (birokrat) haruslah pertama-tama berusaha merubah perilaku masyarakatnya agar dapat menunjang proses modernisasi dan pertumbuhan wilayah. Dengan demikian tugas pokok pemerintah adalah meningkatkan kemajuan dan kesejahteraan masyarakatnya.

Strategi pengembangan sumber daya manusia melalui pendidikan dikemukakan oleh sejumlah ahli, diantaranya Backer dalam kartasasmita (1996) yang mengatakan peningkatan produktivitas dapat didorong melalui pendidikan, pelatihan dan derajat kesehatan. Pendapat serupa juga disampaikan oleh Inkeles dan Smith dalam Wainer (1994), sarana yang paling efektif untuk mengubah pola pikir dan sikap kerja manusia adalah melalui pendidikan. Pendapat ini memberi petunjuk bahwa pengembangan dan peningkatan kualitas sumber daya aparatur di daerah dapat dilakukan dengan meningkatkan pendidikan formal dan non formal seperti memperbanyak mengikuti pendidikan kursus, latihan, magang dan berbagai bentuk pendidikan lainnya yang erat kaitannya dengan tugas dan pekerjaan aparat.

Selain itu, konsep dan strategi lain yang dapat dilaksanakan dalam membina dan mengembangkan potensi sumber daya aparat di daerah adalah dengan mengembangkan sistem rekrutmen yang profesional. Penerimaan pegawai baru misalnya haruslah didasarkan pada kebutuhan obyektif organisasi dan penjaringannya didasarkan atas kemampuan, bukan didasarkan pada patronage system atau nepos system atau spoil system, dimana penerimaan pegawai tidak didasarkan pada pertimbangan keahlian dan keterampilan, melainkan 
didasarkan pada ikatan kekerabatan, sanak famili, kawan dekat, asal daerah yang sama dan kesamaan keyakinan dan ideologi.

Demikian juga dalam penempatan dan pengangkatan aparat pada suatu jabatan, misalnya jabatan struktural/eselon tidaklah atas dasar pertimbangan patronage system, nepos system atau spoil system, akan tetapi penempatan dan pengangkatan aparat dalam suatu jabatan didasarkan rekrutmen meryt (meryt system). Menurut para ahli, meryt system dinilai lebih mempunyai obyektivitas yang tinggi karena dasar pertimbangannya dalam mengangkat/menempatkan pegawai dalam suatu jabatan atas dasar kemampuan atau karena jasa kecakapannya. Jadi duduknya seseorang pada suatu jabatan tidak dikarenakan yang bersangkutan masih kawan dekat, sanak familli dan karena asal etnis yang sama.

Dalam sejarah, rekrutmen berdasarkan patronage system, nepos system, dan spoil system pertama kali dikenal dan dipraktekkan di lingkungan pemerintahan. Dalam kaitan ini Peters dalam (Rasyid, 1995) mengatakan salah satu tema yang sejak lama dipersoalkan dalam diskusi tentang birokrasi adalah ... "the search for efficiency through meryt recruitment". Arti tema ini kurang lebih adalah pencarian efisiensi sebagai suatu kebutuhan yang sangat diperlukan dalam birokrasi pemerintahan dapat dilakukan melalui rekrutmen meryt. Dari pendapat Peters ini dapat disimpulkan bahwa efisiensi dan efektivitas organisasi pemerintahan dalam mencapai tujuan dan sasarannya dapat dicapai dengan menerapkan rekrutmen meryt (menerapkan rekrutmen profesional).

Dengan demikian, untuk mencapai efektivitas penyelenggaraan otonomi luas, maka pengerahan tenaga (aparat) dalam suatu jabatan haruslah mencerminkan ukuran-ukuran kemampuan atas dasar prestasi, bukan atas dasar ikatan perasaan emosional berdasarkan sistem sosial tradisional. Implementasi rekrumen berdasarkan meryt sistem yang mengutamakan pertimbangan prestasi dalam mengangkat pegawai menduduki suatu jabatan sangat tergantung pada kemampuan manajerial seorang pimpinan puncak. Menurut Poder (dalam Manullang, 1981) salah satu fungsi penting dari pimpinan adalah bertanggung jawab untuk menyusun personalia. Pendapat senada dikemukakan oleh Barthos (1990) bahwa tersedianya kemampuan sumber daya manusia dalam organisasi dapat diperoleh melalui manajemen sumber daya yang baik dari top manajemen. Dari pendapat ini memberi petunjuk untuk menciptakan clean birokrasi yang profesional maka diperlukan kemampuan manajerial dari seorang manajemen puncak, misalnya Bupati, Walikota, dan Gubernur.

Faktor lain yang dapat mendorong aparatur di daerah untuk meningkatkan prestasi kerja atau kemampuannya dalam mendukung efektifitas penyelenggaraan otonomi yang luas dan bertanggung jawab adalah memberikan insentif yang memadai dalam memenuhi kebutuhan hidup keluarganya. Menurut Hull dalam (Hartawan, 1997) insentif adalah alatalat yang digunakan dalam mendorong sesorang melakukan sesuatu atau dengan kata lain insentif inilah yang dapat mendorong seseorang mau bekerja sebaik mungkin. Insentif finansial ini dianggap membantu menarik karyawan/ pegawai untuk meningkatkan produktifitas dan semangat kerja.

Dari hasil penelitian para ahli manajemen mengungkapkan adanya korelasi positif antara pemberian insentif yang memadai dengan hasil kerja seseorang. Berdasarakan hasil 
penelitian para ahli manajemen tersebut sehingga dalam organisasi modern banyak diterapkan cara-cara pemberian insentif dalam memacu motifasi kerja para karyawan atau pegawai. Hasil penelitian ini dapat disimpulkan bahwa tingkat pendapatan pegawai sangatlah penting dan menentukan dalam mencapai efektifitas kerja organisasi, karena selain dapat menumbuhkan kejujuran pegawai dalam bekerja, juga dapat mendorong prestasi kerja.

Sayangnya kondisi gaji pegawai negeri Indonesia tergolong sangat rendah dibandingkan dengan negara-negara kawasan Asia Tenggara lainnya seperti Singapura, Malaysia, Thailand dan Filiphina. Oleh karena itu, salah satu sumber penyebab rendahnya kinerja pegawai negeri Indonesia serta suburnya praktek korupsi dan pungutan-pungutan liar (fungsi) adalah akibat rendahnya tingkat pendapatan pegawai negeri.

\section{Semangat Reinventing Government Dalam Pelaksanaan Otonomi Daerah}

Seorang pakar dari Perancis, J.B. Say (dalam Drukken, 1994) menyatakan bahwa wirausaha adalah kemampuan mengubah sumber daya dari yang berproduksi rendah menjadi lebih tinggi atau lebih besar. Kemampuan untuk mengubah sumber daya potensial terdapat pula dalam diri individual, akan tetapi diperlukan pembinaan sehingga bisa menjadi kinerja nyata dalam bentuk usaha-usaha yang memiliki ciri-ciri ekonomi, sistem ekonomi dan gagasan yang dapat meningkatkan produktivitas kerja yang menghasilkan manfaat terhadap lingkungan kerjanya.

Konsep entrepreneuirship adalah suatu konsep yang dikembangkan dari kegiatan ekonomi, namun sifat dan semangatnya bersumber dari teori Mc. Lolecard (1961) yang terkenal dengan simbol N-ACH (Need for Achievement). Teori ini menggambarkan dalam diri manusia terdapat dorongan untuk berprestasi.

Semangat entrepreneurship tidak hanya dibutuhkan di dalam organisasi privat (bisnis), tetapi juga dibutuhkan didalam birokrasi pemerintahan, khususnya lembagalembaga pemberi jasa pelayanan kepada masyarakat seperti yang diungkapkan oleh Osborne dan Gaebler (1992), sifat dan semangat entrepreneurship perlu dimiliki oleh aparatur birokrasi pemerintah dalam melaksanakan fungsi publiknya, mengingat terbatasnya sumber daya yang ada pada pemerintah. Melalui jiwa dan semangat entrepreneurship akan melahirkan pelayanan publik yang efisien, efektif dan produktif.

Dalam upaya melakukan perbaikan birokrasi pemerintahan sering kali kita mendengar istilah "reiventing government". Istilah ini menjadi terkenal ketika presiden AS Clinton melakukan pembaharuan birokrasi pemerintahannya. Apa yang dilakukan oleh Clinton di As tampaknya tidak hanya penting bagi pemerintah Amerika saja, tetapi juga bagi Indonesia , karena prinsip-prinsip yang dikandung di dalam reiventing government itu, bisa diambil sari patinya untuk perbaikan sistem birokrasi pemerintahan Indonesia. Istilah ini sebenarnya sama halnya dengan upaya untuk melakukan pembaharuan. Dan dalam, teori administrasi publik reinventing government ini merupakan manifestasi dari konsep New Publik Manajemen (NPM), karena konsep NPM pada hakikatnya mengadopsi konsep reinventing government. 
Konsep reinventing government di angkat dari berbagai kasus masalah publik di Amerika Serikat yang berhasil di atasi oleh para birokrat lokal karena semangat entreupreunerial (kewiraswastaan) sehingga berhasil mengembangkan inisiatif dan kretivitas warga masyarakatnya. Menurut Osborne dan Gaebler (1992), hakikat reinventing government adalah suatu cara pandang baru dalam melihat fungsi-fungsi pemerintahan. Jadi berlaku padadigma baru dalam melihat bagaimana sebuah pemerintahan dapat menjalankan fungsinya secara produktif dan efisien. Konsep reinventing government lebih menitip beratkan pada pemberdayaan masyarakat untuk mengurangi ketergantungannya kepada pemerintah. Dengan demikian orientasi dari konsep reinventing government (pemerintahan yang berjiwa kewirausahaan) adalah menumbuhkan "kemandirian". Selain itu konsep reinventing government juga menekankan bahwa semua pimpinan (manager) didorong untuk mengembangkan inovasi dan kreativitas untuk memperoleh hasil yang maksimal didalam menjalankan fungsi-fungsi pemerintahan. Mereka tidak lagi memimpin dengan cara-cara melaksanakan semua jenis pekerjaan samapai kepada yang sekecil-kecilnya. Mereka tidak lagi melakukan "rowing" menyapu bersih semua pekerjaan, melainkan melakukan "steering" yaitu membatasi terhadap pekerjaan atau fungsi pengendalian, memimpin, dan mengarahkan yang strategis saja. Disamping itu konsep reinventing government pada manager publik (pimpinan pemerintahan) juga didorong untuk memperbaiki dan mewujudkan akuntabilitas publik kepada pelanggan, meningkatkan kinerja, resturukturisasi lembaga birokrasi publik, merumuskan kembali isi organisasi, melakukan stereamlinning dan prosedur birokrasi, dan melakukan desentralisasi proses pengambilan keputusan.

Secara garis besar Osborner dan Gaebler (1992) mengemukakan sepuluh prinsip yang melandasi konsep reinventing government, sebagai berikut :

1. Pemerintah berfungsi sebagai katalisator (catalytic government). Memungut pajak dan memberikan pelayanan kepada masyarakat adalah satu-satunya fungsi dan peran pemerintah yang selama lebih dari 50 tahun menjadi anggapan dasar dari para publik leaders. Dalam keadaan sumber-sumber publik dan privat (swasta) semakin langka, maka fungsi dan peran pemerintah sebagai pendayung (rowing) hendaknya dialihkan menjadi peran mengarahkan (steering). Atau dengan kata lain fungsi birokrasi pemerintah dialihkan menjadi mengarahkan (steering), dan bukan lagi sebagai pendayung (rowing). Dengan demikian tugas-tugas publik tidak lagi di monopoli pemerintah akan tetapi, masyarakat dilibatkan untuk membantu tugas-tugas publik dari pemerintah sehingga pemerintah tinggal mengarahkan tugas-tugas yang dibebankan kepada masyarakat. Dengan demikian disini terjadi pengalihan fungsi dan peran yang secara kompensional pemerintah berfungsi sebagai pelayan (service) menjadi dapat dikombinasikan dengan kemampuan masyarakat.

2. Fungsi pemerintah dan birokrasi diarahkan untuk pemberdayaan masyarakat. Fungsi memberikan pelayanan publik yang selama ini dijalankan pemerintah harus diarahkan untuk memberdayakan masyarakat dan bukan untuk menumbuhkan ketergantungan yang tinggi yang justru akan menjadi beban pemerintah. Dengan demikian 
"empowering than serving" ialah semangat yang perlu ditumbuhkan dikalangan aparatur pemerintah, karena keberdayaan masyarakat akan mengurangi beban pemerintah dalam memberikan pelayanan publik ketika terjadi ketersediaan sumbersumber publik semakin langka. Karena itulah Montgomery (dalam abdullah, 1988 : 1) dalam mottonya mengatakan : "Modernizing behaviour of citizens could be taken as aprimary taks of development administrator". Arti dari pernyataan ini adalah tugas utama seorang administrator pembangunan haruslah pertama-tama berusaha merubah perilaku masyarakatnya agar dapat menunjang proses modernisasi dan pertumbuhan wilayah tertentu.

3. Competitive government, yaitu Bagaimana menjadikan pemerintahan agar memiliki daya saing tinggi, dengan kata lain mendorong aparatur lokal agar memiliki kemampuan dalam memberikan pelayanan kepada masyarakat sehingga tidak kalah dari sektor swasta, misalnya pelayanan rumah sakit pemerintah harus lebih di atas oleh rumah sakit swasta atau setidak-tidaknya bisa bersaing dengan rumah sakit swasta, pelayanan kantor pos harus lebih di atas oleh Lth, atau tidak ada lagi kasus pengurusan KTP dan izin-izin lainnya yang pengurusannya berbulan-bulan dan memerlukan biaya yang tinggi \{high cost\} di luar dari ketentuan.

Dalam pelaksanaan otonomi daerah sifat kompetitive government harus di tumbuhkan sehingga tidak ada pilihan lain, kecuali dengan menumbuhkan semangat dan jiwa entrepreuneurial kedalam diri setiap aparatur pemerintah. Dengan demikian ditinjau dari sudut administrasi pembangunan yang di harapkan dari seorang administrator pemerintahan adalah agar mampu tampil dan berperan sebagai "birokrat entrepreuneurial", yang memiliki karakteristik kemampuan kepemimpinan, keterampilan profesional dan memiliki visi inovatif yang berorientasi ke depan (Abdullah, 1988: 18)

4. Mengubah sifat rule-driven organization, dari birokrasi pemerintah menjadi "missiondriven government", akan menghilangkan sifat kaku dan berbiaya tinggi dari cara bekerja birokrasi. Pemerintah harus bekerja atas dasar misi utamanya dan bukan atas dasar sucinya aturan. Bagaimana misalnya, jika lingkungan itu berubah karena dalam rumus sosial lingkungan memang tidak pernah berhenti mengalami perubahan, lebihlebih jika perubahan lingkungan berlangsung dengan cepat akibat pengaruh persaingan global ?. oleh karena itu kekauan dalam memberlakukan aturan harus di rubah atas dasar tuntutan yang berkembang di masyarakat. Ini pula yang menjadi inti teori kontingensi dalam teori organisasi yang mengisyaratkan bahwa organisasi dapat maju jika mampu beradaptasi dengan perubahan lingkungan.

5. Result Oriented Government, yaitu pemerintahan harus berorientasi kepada hasil atau prestasi kerja, dan bukan berorientasi pada masukan. Dengan kata lain dalam jiwa aparatur pemerintah baik pusat maupun daerah harus di tumbuhkan semangat agar berorientasi pada prestasi. Untuk menumbuhkan prestasi pada aparatur maka peran manajer pemerintahan, misalnya kepala daerah mamiliki peran sangat penting dan 
menentukan. Kalau seorang kepala daerah menghargai prestasi kerja bawahannya dan di jadikan tolak ukur untuk menempatkan pegawainya pada suatu jabatan tertentu (promosi jabatan), maka para pegawai akan berlombah-lombah untuk bekerja dengan baik. Dengan demikian untuk berorientasi kepada prestasi kerja tidak bisa di pisahkan dengan rekruetmen. Selama ini harus di akui sistem rekruetmen yang masih menonjol di daerah adalah spoyl sistem, dimana pemilihan dan penempatan pegawai untuk menduduki suatu jabatan tertentu didasarkan pada ikatan "kedekatan". Dalam era pelaksanaan otonomi daerah sudah saatnya menerapkan pola rekruetmen yang berorientasi pada meryt sistem.

Selain itu cara lain yang dapat dilakukan untuk berorientasi kepada hasil atau prestasi kerja adalah tentukan terlebih dahulu "out comes" yang di kehendaki dan bukan risau dengan imput atau masukan-masukan. Funding out comes not inputs, bisa diartikan jangan mengejar target, tetapi capailah hasil yang di inginkan dengan dana yang tersedia. Input adalah instrument dan bukan penentu. Yang harus di lakukan adalah bagaimana memaksimalkan hasil atas dasar masukan yang ada.

6. Custumer-driven government yaitu birokrasi pemerintah harus mengutamakan kepentingan dan kebutuham masyarakat sebagai pelanggan, dan bukan memenuhi kepentingan dan kebutuhan birokrasi apalagi menjadi "tuan ". Selama ini masih sebagian besar prilaku birokrat lokal bersifat peodalistik, sehingga prilakunya sebagai "tuan" yang harus di layani masyarakat. Instansi yang di bentuk pemerintah sesunguhnya bukan untuk membebani publik (masyarakat) tetapi untuk mempermudah publik dalam memenuhi kebutuhanya. Jika tidak di terapkan prinsip ini, maka masyarakat akan beralih kepada badan lain yang lebih menjanjikan pelayanan yang cepat dan menyenangkan, sehingga mayarakat akan di kendalikan oleh swasta. Disinilah pentingnya fungsi mengarahkan (stering) dari pemerintah, sebab kehilangan fungsi ini dapat berarti beralihnya kendali atas masyarakat terhadap swasta.

7. Enterprising government yaitu mendorong pemerintah bersemangat wirausaha. Hal ini dapat dilakukan dengan menerapkan earning rather than spending yaitu membuat kinerja pemerintahan sama dengan kinerja organisasi privat (swasta). Jangan membentuk suatu struktur atau unit organisasi pemerintahan jika hanya menyedot anggaran tanpa kejelasan menghasilkan penerimaan pemerintah memang ada kritik terhadap konsep ini karena bisa membuat pemerintah daerah "bermata duit" (oriented money), tetapi itulah konsepkuensi otonomi daerah. Aparat didorong bagaimana mencari dan menggali sumber-sumber pendapatan hasil daerah (PAD), namun jangan dilupakan bahwa dalam menggali sumber-sumber PAD tidak boleh mengorbankan lingkungan yang dapat menimbulkan bencana.

8. Anticipatory government, yaitu menjadikan pemerintah agar memiliki daya antisipasi yang tinggi, artinya karena masa depan penuh ketidakpastian sehingga diperlukan kemampuan aparatur untuk mengantisipasi perubahan yang tidak pernah berhenti dan memiliki resiko. Cara yang paling baik untuk mengantisipasi adalah mencegah ketimbang mengobati, artinya waspada jauh lebih baik dari pada terlambat. 
9. Decentralized government, yaitu menjadikan pemerintahan terdesentralisasi. Desentralisasi pada hakikatnya melonggarkan sentralisasi melalui pelimpahan kewenangan sehingga tumbuh peran serta masyarakat dan aparatur dalam kegiatan pembangunan. Sudah dipahami oleh semua kalangan bahwa sentralisasi bukan hanya memberatkan tugas-tugas pmerintahan, tetapi juga berimlikasi terhadap pembuatan kebijakan yang jauh dari kebutuhan dan keinginan yang didambakan oleh masyarakat. Unit-unit organisasi pemerintahan yang terdesentralisasi akan berfungsi sebagai ujung tombak pelaksanaan fungsi-fungsi pemerintahan. Sebaliknya mempertahankan hirarki melalui sentralisasi akan menjauhkan partisipasi masyarakat dalam kegiatan pembangunan, dan ini berarti beban kerja menjadi terpusat pada pemerintah. Akibatnya pelaksanaan pemerintahan menjadi tidak efektif dan tidak efisien.

10. Market orienteed government, yaitu pemerintahan harus berorientasi pada pasar tetapi jangan diartikan sebagai commersial orienteed. Pasar adalah representasi dari compotitive situation atau situasi persaingan. Pada dasarnya setiap individu maupun kelompok memiliki naluri bersaing tetapi persaingan sehat hanya dapat dikonsepsikan dari situasi pasar, sebab individu maupun kelompok bisa mengarah pada situasi kompotitif yang dapat menumbuhkan kemampuan mendobrak perubahan dan pembangunan tidak lain adalah proses perubahan kearah yang baik.

Ke sepuluh konsep reinventing government yang dibangun oleh Osborne dan Gaebler dari cara pandang baru terhadap pelaksanaan fungsi-fungsi pemerintahan satu sama lain saling terkait yang memberikan kekuatan konseptual bagi peningkatan kinerja birokrasi pemerintah, tidak hanya negara yang sedang berkembang tetapi juga negara maju, sebab konsep reinventing government diangkat dari kenyataan empiris di Amerika Serikat yang warganya sedang bertanya-tanya "apakah pemerintah masih ada"!. Fenomena ini yang ditangkap oleh Osborne yang mantan jurnalis dan city manager untuk menerbitkan buku terlaris reinventing government (1992) dan kemudian dilanjutkan dengan menerbitkan buku lain bersama Peter Plastrik Banishing Bureaucracy (1997). Upaya Osborne ini yang mengenalkan new public managemant dalam birokrasi pemerintah disambut baik oleh pemerintah Bill Clinton yang menindak lanjuti dengan melakukan pembaruan di dalam birokrasi pemerintahannya.

Selanjutnya bagaimana mengembangkan konsep tersebut Osborne dalam buku lanjutannya yang ditulis bersama rekannya Peter Plastrik (1996) yang berjudul Banishing Buerucracy $=$ The Five Stratigies For Reinventing Government. Dalam buku itu beliau menyampaikan lima strategi untuk mengembangkan konsep Reinventing Government sebagai berikut :

1. Strategi inti (Core strategy), yaitu strategi perumusan kembali tujuan-tujuan penyelenggaraan pemerintahan, termasuk otonomi daerah.

2. Strategi konsekuensi ( conseqwensy Strategy), dalam hal ini perlu dirumuskan dan di tata kembali dalam pola insentif kelembagaan dan individual. 
3. Strategi pemakai jasa (customer strategy), aparatur birokrasi dalam hal ini perlu melakukan reorientasi dari kepentingan politik pemerintahan, serta orientasi pada kepentingan kelembagaannya.

4. Strategi pengendalian (control strategy), yaitu adanya perumusan kembali dalam upaya pengendalian organisasi.

5. Strategi budaya/ kultur (culture strategy), yaitu adanya upaya reorientasi prilaku dan budaya aparatur dan birokrasi.

\section{Penutup}

1. Terbitnya UU No. 22 Tahun 1999 tentang pemerintahan daerah, yang kemudian digantikan oleh UU No. 32 tahun 2004 tentang pemerintahan daerah pada hakikatnya banyak memuat gagasan-gagasan pembaharuan dalam menyelenggarakan pemerintahan daerah.

2. Namun harus diakui sejak diberlakukannya UU No. 22 tahun 1999 dan UU No. 25 tahun 1999 tentang perimbangan keuangan antara pemerintah pusat dengan pemerintah daerah, yang kemudian digantikan UU No. 32 Tahun 2004 dan UU No. 33 Tahun 2004, ternyata cenderung diikuti dengan semakin rendahnya kepercayaan masyarakat terhadap birokrasi publik, baik di tingkat pusat maupun di tingkat daerah dalam memberikan pelayanan kepada masyarakat. Krisis kepercayaan ini terhadap birokrasi publik ditandai dengan mengalirnya protes dan demonstrasi yang dilakukan berbagai komponen masyarakat terhadap birokrasi publik. Indikator lain yang menunjukkan masih rendahnya kualitas pelayanan publik adalah dapat dilihat dari lambatnya pelayanan, masih berbelit-belitnya prosedur dalam memperoleh perizinan, diskriminatif dalam memberikan pelayanan serta masih meraja relanya pungutan-pungutan liar diluar dari ketentuan.

3. Pemberian kewenangan yang luas kepada daerah melalui UU No. 22 Tahun 1999 dan digantikan UU No. 32 Tahun 2004, di satu sisi dapat dipandang sebagai kesempatan yang baik bagi daerah untuk lebih maju dan berkembang dalam upaya meningkatkan kesejahteraan masyarakat dan kualitas pelayanan kepada masyarakat. Namun di sisi lain, penyerahan otonomi luas kepada daerah dapat pula dipandang sebagai tantangan baru yang cukup berat, karena pemberian otonomi luas kepada daerah diberlakukan pada saat pemerintah daerah berada dalam kemampuan yang masih terbatas sebagai akibat proses belajar dan penyempitan kreativitas di masa pemerintahan orde baru.

4. Untuk mencegah kekhawatiran dari berbagai kalangan atas kemampuan pemerintah daerah dalam menyelenggarakan otonomi daerah maka tidak ada pilihan lain yang dapat dilakukan oleh pemerintah daerah adalah mengembangkan dan meningkatkan sumber daya aparatur birokrasi di daerah melalui peningkatan pendidikan formal maupun pendidikan nonformal seperti kegiatan kursus, magang, workshop atau dalam pengembangan kode of conduct. Kegiatan ini merupakan sarana yang efektif untuk 
mengubah perilaku dan pola pikir aparatur. Kegiatan lain yang dapat dilakukan untuk meningkatkan kemampuan profesionalisme dan kompetisi dikalangan aparatur adalah dengan mengembangkan sistem rekrutmen yang profesional (meryt sistem). Dari sini akan tumbuh kompetisi yang sehat dikalangan aparatur untuk berorientasi kepada prestasi.

5. Dengan mengembangkan kemampuan sumber daya aparatur birokrasi di daerah melalui kegiatan pendidikan baik pendidikan formal maupun kegiatan nonformal maka akan melahirkan perilaku aparat yang cerdas, kreatif, inovatif, dan berwawasan kedepan. Dari sinilah diharapakan tumbuh semangat entrepreunership dan reinventing government.

\section{DAFTAR PUSTAKA}

Barthos, Basir. 1990. Manajemen Sumber Daya Manusia Suatu Pendekatan Makro. Jakarta. Bumi Aksara.

Bryan, Coralie dan Lois G White. 1987. Manajemen Pembangunan Untuk Negara Berkembang. Jakarta. LP3S. 
Cheema, Shabbir G. Rondinelli A, Dennis. 1984. Decentralization and Development : Polices Implementation In developing Countries, Beverly Hills, London : Sage Publications.

DEPDAGRI OTDA \& BAPPENAS. 2000. Pengembangan Kemampuan Pemerintahan Kabupaten / Kota : Strategi Menuju Otonomi Daerah. Jakarta.

Drueken, Peter, F. 1994. Inovasi dari kewirausahaan, Jakarta. Erlangga.

Dwiyanto, Agus. 2003. Reformasi Tata Pemerintahan dan Otonomi Daerah. Yogyakarta, Pusat Studi Kependudukan dan Kebijakan.

Dwiyanto, Agus. 2008. Mewujudkan Good Governance Melalui Pelayanan Publik. Yogyakarta, Gadjah Mada University Press.

Edward III, George. C. 1980. Implementing Publik Policy. Washinton DC : Congreesional Quartery Press.

Gaebler, Ted dan Osborne David. 1992. Mewirausahakan Birokrasi : Mentrasformasi Semangat wirausahaan Kedalam sektor Publik. Jakarta. Taruna grafika.

Harian Pikiran Rakyat. 1996. Otonomi Tuntut Adanya Birokrasi Profesional. Bandung.

Harvey Sillars, Barbara 1984. PERMESTA, Pemberontakan Setengah Hati, Jakarta, grafiti Pers.

Henry, Nicolas. 1988. Administrasi negara dan masalah-masalah kenegaraan. Jakarta Rajawali Press.

Kartasasmita, Ginandjar, 1996. Pembangunan Untuk Rakyat. Memadukan Pertumbuhan dan Pemerataan. Jakarta. Pustaka CideCindo.

Kartiwa, Asep. 2009. Bahan Kuliah Teori Manajemen Publik Kontemporer. Program Doktor Adminstrasi Publik, Program Pascasarjana Fisip Unpad Bandung.

Luthan Fred, 1992. Organizational Behavioral. New York: Mc. Graw Hill.

Manullang, M. 1981. manajemen personalia. Jakarta. Galia Indonesia.

Mc. Lellang. 1961. The achiusing Society, Printeton, N.J : Van Nostrand.

Osborne, David dan Plastrik, Peter. 2000. Memangkas Birokrasi Lima Strategi Menuju Pemerintahan Wirausaha. Jakarta, PPM, Anggota Ikapi.

Rasyid, Ryaas, M. 2002. Otonomi daerah : latar belakang dan masa depan. Jakarta, AIPI (Asosiasi Ilmu Politik Indonesia). 
Ratminto dan Atik Septi Winarsih. 2009. Manajemen Pelayanan : Pengembangan Model Konseptual, Penerapan Citizen's Charter dan Sandar Pelayanan Minimal. Yogyakarta, Pustaka Pelajar.

Sedermayanti, 2003, Good Governance (Kepemerintahan yang baik) Dalam Rangka Otonomi Daerah. Upaya Membangun Organsiasi Ekesekutif dan Efisien melalui Rektrukturisasi dan Pemberdayaan Bandung Modern Maju.

Smith, B.C. 1985. Dezentralitation, George Allen And Howin. ITD London

Supriatna, Tjahya. 1993. Sistem Administrasi Pemerintahan di Daerah. Jakarta. Bumi Aksara.

Suradinata, Ermaya 1993, Kebijaksanaan Pembangunan dan pelaksanaan Otonomi Daerah. Bandung Ramadhan.

Undang-Undang No. 22 Tahun 1999 Tentang Pemerintahan Daerah dan Undangundang No. 25 Tahun 1999 Tantang Perimbangan Keuangan Antara Pemerintah Pusat dan Daerah.

Syafruddin, Ateng. 1985. Pasang Surut Otonomi Daerah. Bandung Bina Cipta.

Thoha, Miftah. 2008. Ilmu Administrasi Publik Kontemporer. Jakarta, Kencana Prenada Media Group.

Utomo, Warsito. 2007. Administrasi Publik Baru Indonesia : Perubahan Paradigma dari Administrasi Negara ke Administrasi Publik. Yogyakarta, Pustaka Pelajar.

UU no 32 tahun 2004. Tentang pemerintahan daerah dan UU no 33 tahun 2004 tentang perimbangan keuangan antara pemerintah pusat dan daerah. Bandung, Citra Umbara.

Wainer, Myron. 1994. (ed). Modernisasi Dinamika Pertumbuhan. Yokyakarta, Gadjah Mada University Press. 